\title{
OPTIMALISASI POTENSI KARYA MAHASISWA MATA KULIAH GRAFIKA DKV MELALUI GALERI ONLINE
}

\author{
Annas Marzuki Sulaiman ${ }^{1}$, Sugiyanto ${ }^{2}$ \\ Jurusan Desain Komunikasi Visual,Fakultas Ilmu komputer \\ Universitas Dian Nuswantoro Semarang \\ Jl. Nakula 1-6 Semarang ${ }^{1,2}$ \\ Email: anazdesign@gmail.com
}

\begin{abstract}
Graphic reproduction courses or printing methods are one of the courses that always exist in every college of Visual Communication Design in Indonesia, with this course students are expected to understand how the Final Artwork (FA) printing process is correct, the result is the quality of the design work Finally, students have met printready standards in accordance with the graphic industry standard so that it has the potential to be offered to the public at large as ready-to-use works, but unfortunately the student's work has only ended up in storage. This study aims to optimize the potential that exists in the final design work to be more widely useful. This study uses a qualitative method with a descriptive approach aimed at analyzing the quality of student design assignments in the Gafika Reproduction Method course, and creating an online gallery as a means of channeling existing design potential.
\end{abstract}

Keywords: Optimization, DKV, Graphic Reproduction Method, Online Gallery

\begin{abstract}
Abstrak: Mata kuliah reproduksi grafika atau metode percetakan merupakan salah satu mata kuliah yang selalu ada pada setiap perguruan tinggi Desain Komunikasi Visual di Indonesia, dengan mata kuliah ini diharapakan mahasiswa memahami bagaimana proses percetakan Final Artwork (FA) secara benar, hasilnya kualitas penciptaaan karya desain akhir mahasiswa sudah memenuhi standar yang siap cetak sesuai standar industri grafika sehingga mempunyai potensi untuk ditawarkan kepada masyarakat secara luas sebagai karya siap pakai namun sayangnya karya mahasiswa tersebut selama ini hanya berakhir di tempat penyimpanan. Penelitian ini bertujuan untuk mngoptimalkan potensi yang ada pada karya desain akhir supaya lebih bermanfaat secara luas. Penelitian ini menggunakan metode kualitatif dengan pendekatan diskriptif bertujuan untuk menganalisis kualitas karya tugas desain mahasiswa pada mata kuliah Metode Reproduksi Gafika, dan menciptakan galeri online sebagai sarana penyaluran potensi desain yang ada.
\end{abstract}

Kata kunci: Optimalisasi, DKV, Metode Reproduksi Grafika, Galeri online

Saat ini telah banyak institusi dan industri yang membutuhkan tenaga kreatif bidang desain komunikasi visual untuk menyelesaikan berbagai permasalahan komunikasi visual yang menyangkut institusi atau industri tersebut. Berbagai institusi dan industri yang bergerak di bidang komunikasi visual antara lain meliputi bidang grafika (penerbitan dan percetakan), periklanan, penyiaran televisi, biro iklan, biro desain, rumah produksi multi media, biro animasi, humas lembaga pemerintah maupun swasta, wiraswasta, dan sebagainya (Kusrianto, 2009:4).
Desain Komunikasi Visual semakin besar dalam menentukan hitam-putihnya Pendidikan Tinggi Desain Komunikasi Visual di Indonesia karena telah menjadi bagian terbesar penyelenggara pendidikan Desain Komunikasi Visual. Perguruan Tinggi Swasta merupakan bentuk penyelenggaraan pendidikan yang didirikan oleh masyarakat dalam kontribusinya terhadap pendidikan nasional (Hastjarjo, 2011:667)

Meningkatnya kebutuhan tenaga kreatif bidang desain komunikasi visual tersebut mendorong beberapa perguruan tinggi untuk membuka jurusan atau program studi 
Desain Komunikasi Visual, salah satunya adalah Universitas Dian Nuswantoro Semarang. Pada program studi tersebut mengajarkan berbagai mata kuliah yang menunjang kebutuhan berbagai bidang industri kreatif yang bergerak pada ranah desain komunikasi visual. Salah satu diantaranya adalah mata kuliah Metode Reproduksi Grafika, yang menunjang industri grafika (penerbitan atau publishing dan percetakan). Dimana industri grafika saat ini menjadi salah satu industri kreatif yang berkembang dengan pesat, terutama di bidang penerbitan. Meskipun banyak kalangan yang menyatakan bahwa industri penerbitan mengalami penurunan karena digitalisasi tapi kenyataanya penerbitan adalah industri yang bergerak tidak hanya pada ranah fisik berupa yang di cetak, namun sudah memasuki ranah digital dalam bentuk elektronik (Pesik: 2018, diakses 10 April 2018).

Mata Kuliah Metode Reproduksi Grafika bertujuan agar mahasiswa memahami proses pembuatan karya desain komunikasi visual yang baik dan benar, sehingga menghasilkan karya akhir yang siap dicetak dan dipublikasikan pada khayalak atau disebut dengan istilah Final Artwork (FA). Pembuatan Final Artwork (FA) dalam penciptaan karya desain komunikasi visual merupakan standar kualitas dalam industri grafika pada khususnya dan industri yang berkaitan dengan desain komunikasi visual lainya. Sehingga mahasiswa mampu mengasilkan karya-karya desain yang sudah memenuhi standar idustri dan sudah layak digunakan untuk memenuhi kebutuhan masyarakat secara luas.

Namun selama ini karya-karya mahasiswa mata kuliah Metode Reproduksi Grafika tersebut setelah mendapatkan nilai dari dosen hanya disimpan kedalam media penyimpanan bila berupa file atau hanya ditumpuk di gudang bila berupa hasil cetakan. Setelah lama berlalu sebagian karya-karya mahasiswa tersebut digunakan sebagai referensi untuk kampus, akan tetapi sebagian besar lainya akan dilupakan dan hilang. Karyakarya mahasiswa yang dihasilkan diantaranya desain undangan pernikahan, desain buku dan layout buku serta desain katalog, yang semuanya lengkap dengan file sumbernya yang dapat digunakan sebagai templet yang siap digunakan untuk cetaka berulang.
Berdasarkan permasalahan yang telah diuraikan diatas maka penulis mempunyai inisiatif untuk memanfaatkan karya-karya mahasiswa mata kuliah grafika sehingga mempunyai nilai ekonomis dimana hasinya dapat dimanfaatkan oleh pihak mahasiswa pihak kampus, dan dapat dimanfaatkan masyarakat secara luas. Dengan demikian, mahasiswa dapat terpacu untuk menciptakan karya yang kreatif, inovatif, dan memperhatikan standar kualitas karya akhir agar sesuai dengan standar industri dengan membuat situs e-galeri karya mata kuliah Grafika UDINUS. Selain itu, peneliti juga akan menyusun suatu pedoman standarisasi penciptaan karya akhir desain atau Final Artwork (FA).

Menurut Kamus Besar Bahasa Indonesia Istilah pengoptimalan berasal dari kata dasar optimal yang berarti terbaik, tertinggi, dan paling menguntungkan. pengoptimalan atau optimalisasi merupakan proses, cara, perbuatan mengoptimal-kan yaitu menjadikan paling baik, paling tinggi, paling menguntungkan, dan sebagainya (Badan Pengembangan dan Pembinaan Bahasa: 2016). Dalam hal ini pengoptimalan karya desain mahasiswa mata kuliah metode reproduksi grafika merujuk pada cara atau proses membuat hasil karya tersebut menjadi lebih fungsional, lebih efektif, dan lebih menguntungkan.

Secara estimologi metode reproduksi grafika terdiri dari tiga suku kata yaitu metode, reproduksi dan grafika menurut kamus bahasa Indonesia pengertian ketiga kata tersebut adalah: 1) metode adalah cara teratur yang digunakan dalam melaksanakan suatu pekerjaan supaya tercapai sesuai dengan yang diharapkan: cara kerja yang bersistem untuk memudahkan pelaksanaan suatu kegiatan agar mencapai tujuan yang ditentukan; 2) reproduksi yaitu pengembangbiakan; memperbanyak; tiruan; hasil ulang; 3) grafika yaitu ilmu tentang cetak-mencetak (pada kertas atau logam) (https://kbbi.web.id/grafika). Sehingga dari ketiga pengertian tersebut, Metode Reproduksi Grafika dapat diartikan sebagai segala cara teratur dalam mewujudkan bentuk visual berupa huruf, tanda, dan gambar yang diperbanyak melalui proses percetakan yang disampaikan kepada masyarakat luas. 
Produk cetak dikategorikan ke dalam pencetakan komersial dan majalah. Klasifikasi ini membedakan barang cetakan dengan frekuensi publikasi. Karena proses produksi juga sangat bergantung pada kondisi dasar ini, percetakan biasanya mengkhususkan pada satu atau segmen pasar lainnya. Pencetakan komersial mengacu pada produk cetak yang diproduksi sesekali (misalnya, katalog, brosur, selebaran, kartu nama, dll.). Periodik adalah materi cetak yang muncul secara berkala (misalnya surat kabar, jurnal, majalah). Penerbitan rumah dan perusahaan adalah klien tipikal untuk dicetak secara berkala (Helmut, 2001:1).

Dalam reproduksi grafika terdapat urutan proses produksi. Urutan produksi yang ada dalam produksi media cetak terdiri dari tahapan 1) prepress, 2) proses pencetakan aktual (press), dan 2) finishing (postpress) (Helmut, 2001:14). Tahap-tahap produksi individu ini dihubungkan oleh aliran material, seperti pelat cetak antara prepress dan press dan lembaran yang dicetak antara press dan postpress. tahap produksi telah menjadi semakin ditandai oleh aliran data. Informasi diubah baik untuk produksi aktual produkproduk cetakan khusus dan untuk organisasi bisnis dan siklus produksi. Informasi dan data merupakan persyaratan penting untuk fungsi proses produksi individual yang optimal dan dapat diandalkan. Untuk lebih jelasnya dapat dilihat pada gambar berikut ini.

Untuk bisa menghasilkan karya terbaik yang sudah memenuhi standar percetakan maka perlu dipersiapkan sebuah desain final. Desain final atau final artwork (FA) adalah istilah untuk file-file desain akhir siap untuk dicetak. Ada beberapa hal penting yang perlu diperhatikan dalam penyusunan suatu karya seni akhir. Beberapa hal ini sangat penting untuk menghindari kesalahan pada saat pencetakan yang dapat berdampak pada hasil produksi yang buruk. Beberapa hal tersebut antara lain (Tiadi, 2010:61): (1) Apakah Bleed Sudah Ada?; (2) Apakah Crop Mark Sudah Ada?; (3) Apakah Font Sudah Di Convert?; (4) Apakah Resolusi sudah sesuai?; (5) Apakah Color Mode Sudah Benar?; (6) Apakah Ukuran Artwork Sudah Benar?; (7) Apakah Link Gambar Sudah Lengkap?

Galeri merupakan wadah untuk seni yang dipamerkan dan memiliki kualitas visual tersendiri yang memengaruhi pengalaman seseorang tentang seni yang dikandungnya (Carrier, Jones, 2016:2). Menurut Djulianto (Koran Tempo, 2013), galeri adalah tempat menjual benda seni. Istilah online berarti mendapatkan akses untuk internet dan menggunakan internet (Matthew, 2004:273). Berdasarkan pengertian-pengertian di atas maka Galeri online dapat diartikan sebagai wadah untuk memajang karya seni yang dipamerkan dan diperjual belikan secara online yaitu melalui internet.

\section{METODE}

Penelitian ini menggunakan metode kualitatif dengan pendekatan diskriptif sehingga dapat menjelaskan permasalahan dengan mengambil sudut pandang tertentu untuk mendiskripsikan, menggambarkan, menguraikan, atau memaparkan sebaik mungkin fenomena yang diteliti atau dipelajari (Ahimsa, 2000:21). Penelitian ini dilaksanakan di dalam laboratorium dan kelas teori pada mata kuliah Metode Reproduksi Grafika, di perpustakaan, dan juga di ruang tempat pengumpulan karya mahasiswa di lingkungan program studi S1 Desain Komunikasi Visual Universitas Dian Nuswantoro Semarang. Sumber data diperoleh dari wawancara terhadap mahasiswa dan dosen di lingkungan Universitas Dian Nuswantoro Semarang mengenai fenomena-fenomena yang ada. Data juga diperoleh dari sumber tertulis (literatur), dan foto (dokumentasi). Sehingga penelitian ini akan menghasilkan data-data deskriptif mengenai permasalahan yang diangkat.:

\section{HASIL}

Selama ini secara estetis sudah ada beberapa karya mahasiswa DKV Udinus khusnya karya tugas mata kuliah Metode Reproduksi Grafika yang sudah terlihat bagus dengan teknik desain yang matang. Sebagai tugas atau projek dalam perkuliahan maka karya-karya mahasiswa tersebut setelah mendapatkan penilaian dari dosen akan berakir sebagi bahan reverensi kampus bila karyakarya terbut mendapat nilai bagus dan yang mendapat nilai kurang bagus akan dikembalikan pada mahasiwa sebagai bahan referensi mahasiswa. Lama-kelamaan karya2 tersebut baik yang dijadikan koleksi referensi kampus maupun yang dikembalikan pada 
mahasiswa kebanyakan akan lapuk atau dibuang begitu saja. Menurut penulis hal ini sangat disayangkan mengikat karya-karya tersebut sebenarnya memiliki nilai jual.

Pembuatan situs galeri online yang beralamat di www.galeridesain.com menjadi wadah bagi penyaluran kreatifitas sekaligus membuka peluang ekonomis bagi karya mahasiswa mata kuliah metode reproduksi grafika. Dengan dibuatnya situs tersebut dosen menawarkan mahasiswa untuk dapat memasukkan karyanya dengan syarat dan ketentuan yang sesuai dengan standar industri. Sehingga mau tidak mau mahasiswa menjadi lebih terpacu dan bersungguh-sungguh dalam menghasilkan karya-karya terbaiknya .

Tabel 1. Optimalisasi Karya Mahsiswa Metode Reproduksi Grafika melaui galeri online

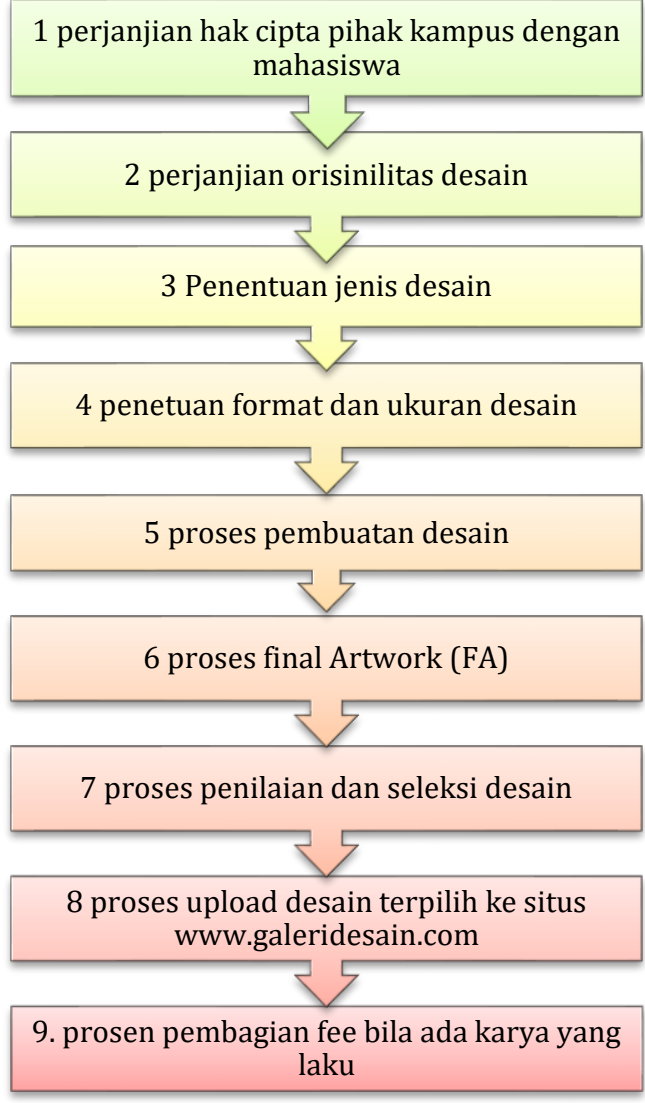

Tabel tersebut dapat dijabarkan sebagai berikut:

\section{Perjanjian hak cipta pihak kampus - mahasiswa}

Sejak awal dimulainya kelas mata kuliah Metode Reproduksi Grafika Mahasisawa sudah di informasikan mengenai tugas/projek apa saja yang akan dikerjakan selama perkuliahan (ada 2 tugas/projek) sehingga mahasiswa mempunyai persiapan dari awal. Selain itu juga sudah diberitahukan kepada mahasiswa bahwa karya mereka kemungkinan akan dipasarkan melalui situs www.galeridesain.com yang bisa menghasilkan nilai ekonomis, sehingga perlu dilakukan perjanjian hak cipta antara dosen yang mewakili institusi dengan mahasiswa mengenai kepemilikan karya dan kemungkinan pembagian hasil bernilai ekonomis.

\section{Perjanjian orisinilitas desain}

Setelah perjanjian hak cipta ini disepakati maka perlu juga dilakukan kesepakatan dengan mahasiswa bahwa karya-karya mereka yang akan dikerjakan dalam rojek/tugas harus benarbenar original bukan hasil penjiplakan karya orang lain yang ditandai dengan pembuatan surat pernyataan orisinal karya masing-masing mahasiswa

\section{Penentuan jenis desain}

Setelah semua kontrak selesai dilakukan maka dosen akan menentukan jenis karya apa saja yang akan dibuat. Penentuan jenis karya ini berdasarkan dari tingkat keterserapan ilmu yang diajarkan dan tingkat kterserapan karya di masyarakat atau industri. Sementar ini karyakarya yang dibuat meliputi Desain Cover buku umum, Lyout buku umum, desain undangan pernikahan, dan katalog. Jenis karya ini dapat berubah dan berkembang sewaktu-waktu sesuai perkembangan jaman

\section{Penetuan format dan ukuran desain}

Penentuan format dan ukuran desain ini dilakukan supaya desain yang dibuat oleh mahasiswa tidak menggunakan sembarang ukuran dan format namun menggunakan standar ukuran sesuai dengan standar industri supaya tidak mengalami kesulitan saat akan dictak dan juga untuk menghindari pemborosan karena kelebihan maupun kekurangan ukuran.

\section{Proses pembuatan desain}

Pada proses pembuatan desain, mahasiswa mengerjakan desainya secara langsung pada saat perkuliahan di lab maupun tugas dirumah. Dosen melakukan bimbingan dan pengajaran secara terstruktur sesuai dengan kurikulum yang ada untuk menyelesaikan karya desain tersebut tahap 
demi tahap sejumlah dua karya desain yang dibuat dalam dua tahapan. Yaitu dari awal perkuliahan sampai dengan Ujian Tengah Semester untuk menghasilkan karya desan pertama dan setelah uts sampai dengan Ujian Ahir Semester.

Dalam proses pembuatan karya tersebut terdapat capaian target-target tertentu untuk meningkatkan kemampuan mahasiswa dalam menyelesaikan tugas dan akan dininilai sebagai tuga harian. Kemudian setiap akhir perkuliahan karya yang sudah jadi akan menjadi karya tugas tengah semester dan karya tugas akhir yang masing-masing akan dinilai, namun sebelumnya harus melalui tahap ceklist persiapan karya akhir / Final Artwork (FA).

\section{Proses final Artwork (FA)}

Final artwork (FA) adalah istilah untuk file-file desain akhir siap untuk mencetak dalam dunia industri Grafika. Ada beberapa poin penting yang harus diperhatikan dalam penyusunan karya desain akhir. Poin ini sangat penting untuk menghindari kesalahan pada saat pencetakan yang dapat berdampak pada hasil produksi yang buruk. Berikut ini poin-poin yang harus diperhatikan untuk memenuhi standar kualitas desain cetak:

a. Penggunaan Bleed

Bleed merupakan elemen desain berupa area yang disengaja dilebihkan selebar 3 $\mathrm{mm}$ tujuanya untuk menghindari kesalahan saat pemotongan yang dapat terjadi ketika halaman tersebut dipangkas terlalu banyak.

b. Penggunaan Crop Mark

Crop Mark merupakan elemen desain yang disengaja, untuk bleed untentional dapat terjadi ketika halaman tersebut dipangkas terlalu banyak.

c. Penggunaan Font

Font untuk final artwork harus dikonversi terlebih dahulu ke dalam bentuk kurva. Hal ini untuk menghindari hilang atau font font yang tidak dikenali. Selain itu, untuk font yang tidak diinstal secara default pada OS yang paling umum seperti Windows dan Mac.

d. Penggunaan Resolusi

Kebutuhan resolusi pencetakan perlu diatur sesuai desain dan tujuan desain yang ingin dicapai. Sebuah resolusi standar yang baik berkualitas tinggi untuk desain cetak ukuran buku dan poster A3 adalah 250-300 ppi/dpi. Tapi ada pengecualian untuk cetakan besar seperti billboard. Untuk jenis cetak luar ruangan seperti ini, resolusi yang baik adalah 72 $150 \mathrm{ppi} / \mathrm{dpi}$

e. Penggunaan Color Mode

Pastikan mode warna pada artwork telah dikonversi ke CMYK dan bukan RGB. Karena, proses pencetakan dan pencetakan hanya dapat menangani modus CMYK, dan biasanya, mesin cetak / print secara otomatis akan mengkonversi RGB ke mode warna CMYK. Hal ini tentu akan mempengaruhi kualitas warna dalam desain. Jadi, pastikan warna sesuai dengan desain yang diinginkan dalam mode warna CMYK.

f. Penggunaan Ukuran Artwork

Ukuran artwork desain cetak harus dipastikan sudah menggunakan ukuran yang sebenarnya (Actual Pixel). Jangan sampai gambar untuk pixelate sebagai ukuran file artwork lebih kecil atau lebih dari ukuran sebenarnya.

g. Penggunaan Gambar

Beberapa aplikasi grafis seperti Adobe Illustrator secara default menampilkan gambar (gambar) dengan link ke folder di komputer Anda. Hal ini untuk menghemat kapasitas file artwork yang kita kerjakan. Jika file tersebut dipindahkan ke komputer lain, maka gambar akan muncul pada desain tidak dapat ditemukan. Prinsipnya adalah sama seperti font, kita bisa menggunakan fungsi embed untuk memasukkan gambar secara penuh pada file tersebut.

h. File Format Standar Percetakan

Hal lain yang perlu diperhatikan adalah saat penyimpanan file yang akan dicetak. File-file yang akan dibawa ke percetakan harus berupa file-file standar yang biasa diguakan percetakan dalam mendesain diantaranya Adobe Photoshop, Iluustrator, Indesign, Corel Draw, dan Quark Express. Selain itu juga ada beberapa file gambar yang bisa digunakan yang berformat bitmap diantaranya adalah TIFF, PDF, EPS dan AI.

7. Proses penilaian dan seleksi desain

Karya-karya mahasiswa yang akan dimasukkan dalam situs 
www.galeridesain.com merupakan karyakarya pilihan terbaik baik dari sisi estetis maupun sisi teknis, yang pengerjaanya melalui pengawasan dan bimbingan dosen sehingga bisa terjaga standar mutunya. Karya tersebut juga sudah di cek untuk dapat memenuhi kriteria karya akhir (Final Artwork) dan layak untuk dipublikasikan. Beberapa karya yang terpilih antara lain:

a. Contoh Karya desain cover buku

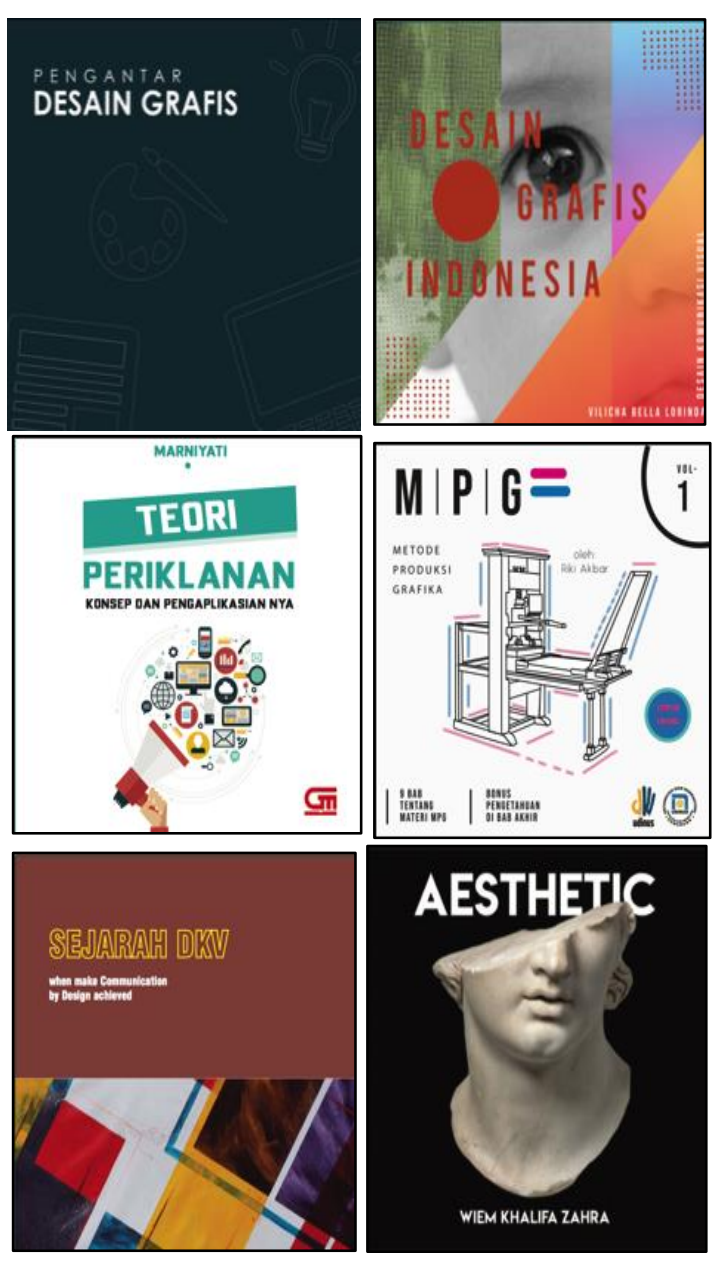

Gambar 1. Desain Cover

Sumber: Dokumentasi Annas

b. Contoh Karya layout buku
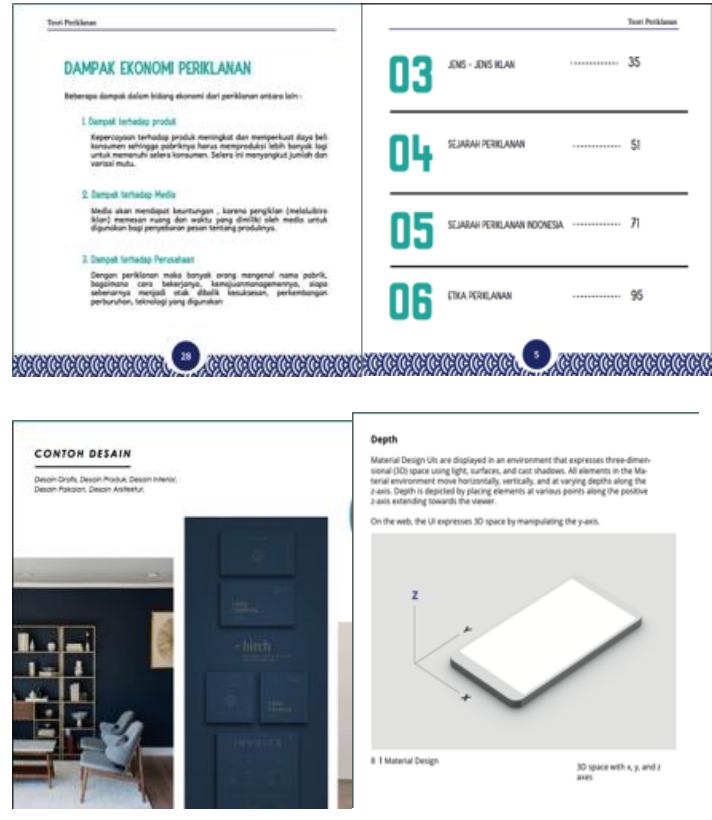

Gambar 2. Desain Layout

Sumber: Dokumentasi Annas

c. Contoh Karya undangan pernikahan
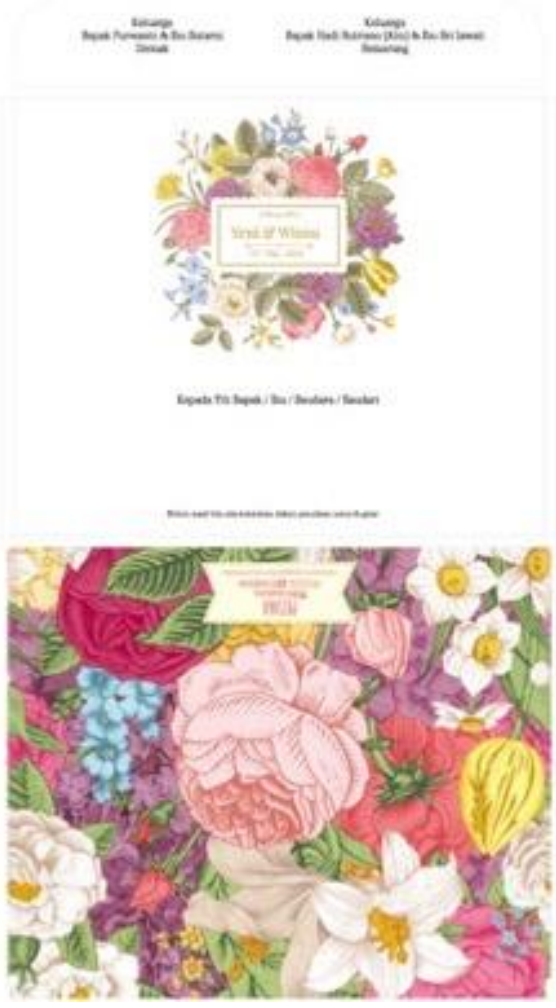

Gambar 3. Desain UNDANGAN

Sumber: Dokumentasi Annas

8. Proses upload desain terpilih ke situs www.galeridesain.com 
Karya-karya terpilih yang telah lolos seleksi kemudian disiapkan file tumbnail dalam format jpge dan file aslinya dalam format AI, Psd, dan indd. File jpg sebagai preview untuk memudahkan pengunjung situs melihat tampilan desain yang sudah dibuat. Setelah pengunjung membilih dan membeli karya yang diingankan maka pengunjung akan diberikan link untuk mendownload file asli lengkap dengan link gambar maupun font yang dibutuhkan dari penyimpanan di google drive.

\subsection{Konsep dan Desain Situs www.galeridesain.com}

Situs www.galeridesain.com merupakan situs yang berfungsi sebagai galeri tempat memajng karya-karya desain dan layoutdari mata kuliah Metode Reproduksi Udinus. Selain itu juga sebagai sarana untuk memasarkan karya-karya yang potensial untuk diterima pasar. Karya-karyamahasiswa yang ditawarkan di situs ini berupa tempelate jadi dengan desain yang lengkap dengan berbagai format ukuran yang sesuai standar industri dan sudah siap cetak karena sudah berupa Final Artwork (FA) untuk saat ini terdiri dari tiga kategori yaitu Desain cover buku, desain layout buku, dan desain undangan pernikahan. Jenis karya tersebut memngkinkan untuk dikembangkan atau ditambah sesuai dengan kebutuhan.

Karya-karya desain tersebut sudah siapa pakai dengan hanya mengganti tulisan saja sesuai kebutuhan sehingga akan memudahkan masyarakat atau industri yang menggunakanya tanpa perlu kehilangan banyak waktu, tenaga, dan pikiran untuk mendesain. Selain itu harga templet desain yang ditawarkan cukup terjangkau yaitu kisaran 20.000 rupiah saja. Masing-masing mahasiswa yang telah lolos seleksi untuk memasukkan karya ke situs www.galeridesain.com akan didata secara lengkap data dirinya, alamat dan nomer telepon untuk mempermudah proses administrasi berkaitan dengan pembagian fee maupun proses administrasi lainya yang mungkin diperlukan.

Berikut ini tampilan desain situs www.galeridesain.com:

a. tampilan halaman depan

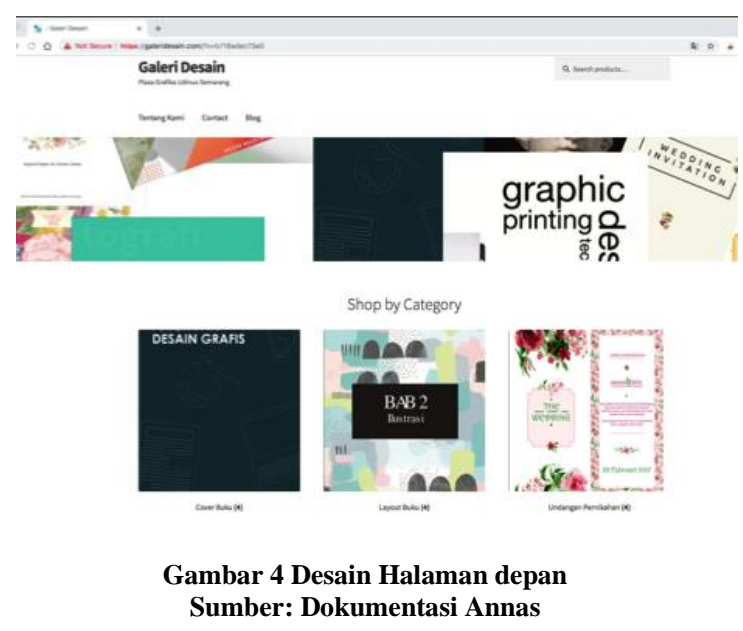

b. Tampilan halaman galeri karya

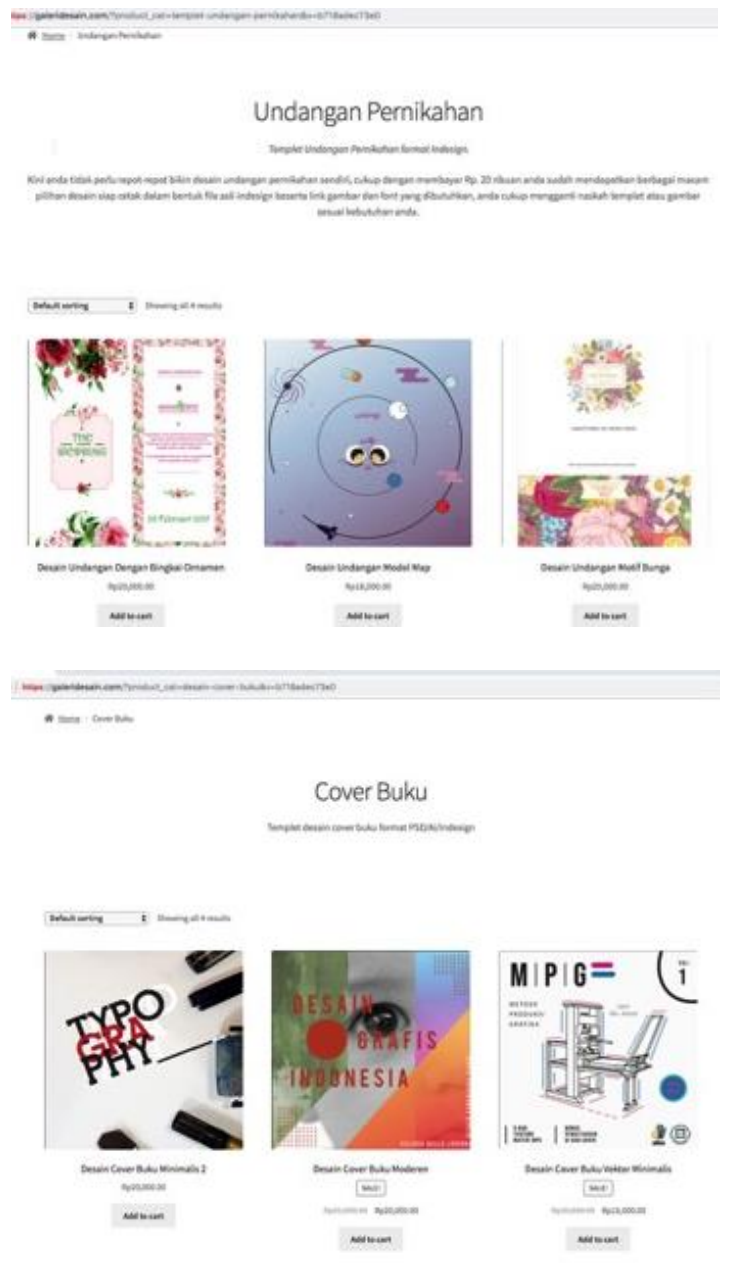

Gambar 5. Desain Halaman Galeri Karya

Sumber: Dokumentasi Annas

c. Tampilan halaman tentang kami 


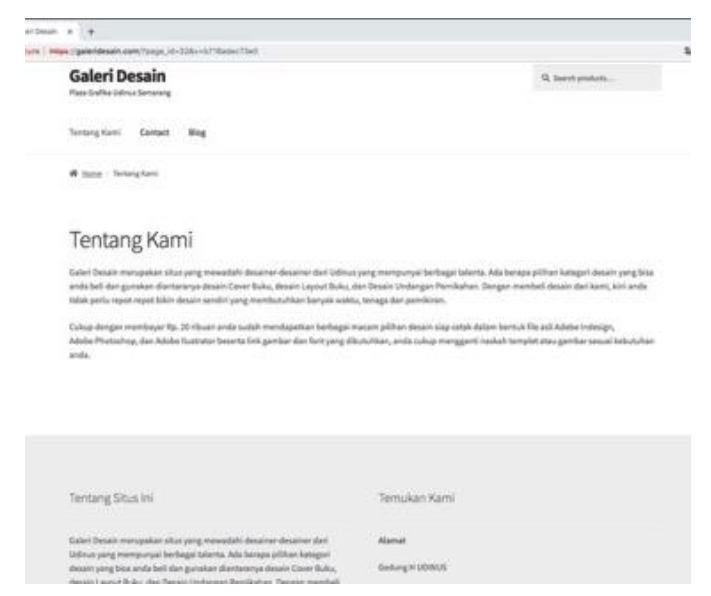

Gambar 6. Desain halaman tentang kami Sumber: Dokumentasi Annas

\section{KESIMPULAN}

Setelah menganalisis permasalahan berkaitan dengan perkuliahan Metode Reproduksi Grafika di Universitas Dian Nuswantoro ditemukan berbagai permasalahan diantaranya masih rendahnya kualitas hasil akhir karya desain mahasiswa, masih adanya penjiplakan karya desain, dan kurang dihargainya karya desain mahasiswa. Untuk mendukung pencapaian standar kualitas akhir karya mahasiswa agar sesuai dengan standar industri dan mempunyai nilai ekonomis, peneliti mengidentifikasi permasalahan yang ada dan membuat suatu galeri karya mahasiswa online berupa situs www.galeridesain.com, maka dengan dibuatnya situs tersebut dapat meberikan beberapa manfaat antara lain:

1. Dapat berfungsi sebagi wadah penyaluran kreatifitas sekaligus sebagai bentuk literatur desain untuk masyarakat luas.

2. Mahasiswa menjadi lebih terpacu dalam meciptakan karya-karya terbaik mereka

3. Karya-karya mahasiswa dapat lebih bermanfaat bagi masyarakat luas untuk menyelesaikan berbagai solusi desain

4. Mahasiswa menjadi lebih memperhatikan tentang pentingnya hak cipta

5. Mahasiswa mampu menciptaan karya desain grafis yang siap cetak berupa Final Artwork (FA) sebagai sandar kualitas desain yang sesuai dengan standar industri

6. Membuka peluang ekonomis bagi karya mahasiswa mata kuliah metode reproduksi grafika
7. Memacu mahasiswa untuk berwira usaha dibidang percetakan.

Hasil penelitian berupa pembuatan situs galeridesain ini diharapkan akan meningatkan mutu, kualitas dan nilai ekonomis dari pencipan karya desain akhir mahasiswa pada mata kuliah Metode Repruksi Grafika sesuai dengan standar industri.

\section{DAFTAR PUSTAKA}

Badan Pengembangan dan Pembinaan Bahasa. 2016. Kamus Besar Bahasa Indonesia. (KBBI). (https://kbbi.web.id/grafika). Diakses 10 Maret 2019

Badan Pengembangan dan Pembinaan Bahasa. 2016. Kamus Besar Bahasa Indonesia. (KBBI). https://kbbi.web.id/optimal. Diakses 12 Maret 2019

Ahimsa Putra, Heddy Shri .2000.Ketika Orang Jawa Nyeni. Yogyakarta: Galang Press dan Yayasan Adhi Karya

Gere, Charles (2008) New Media Art and the Gallery in the Digital Age. In: New Media in the White Cube and Beyond : Curatorial Models for Digital Art. University of California Press, hal. 13-25.

Kipphan, Helmut. 2001. Handbook of Print Media. Springer : Berlin

Kusrianto, Adi. 2009. Berkarier di Dunia Grafis. Jakarta: Elex Media Komputerindo

Triadi, Dendy. 2010. Memahami Teori \& Praktek Iklan Media Lini Bawah. Elex Media Computerindo: Jakarta

Hastjarjo, Boedi. 2011. Relasi Antara Perguruan Tinggi Desain Komunikasi Visual (DKV) Di Indonesia Dengan Industri Dkv HUMANIORA Vol.2 No.1 April 2011

Pesik. 2018. Bicara industri kreatif indonesia di KLKIBF 2018. www.bekraf.go.id/berita/page/8/bicar a-industri-kreatif-indonesia-di-klibf2018,10 April 2018

Susilo, Djulianto. 2013. Galeri Itu Bukan Museum. Jakarta: Tempo. https:// koran.tempo.co /read/ 330074/galeriitu-bukan-museum?read=true

Carrier, David, Jones, Darren. 2016. The Contemporary Art Gallery: Display, 
Annas Marzuki Sulaiman, Sugiyanto

OPTIMALISASI POTENSI KARYA MAHASISWA MATA KULIAH GRAFIKA DKV MELALUI GALERI ONLINE

Power and Privilege. Cambridge:

Cambridge Scholars Publishing 